\title{
PENGARUH BEBAN KERJA DAN KECERDASAN EMOSIONAL TERHADAP KELELAHAN KERJA (BURNOUT) DAN KINERJA PERSONEL POLRES BARITO SELATAN DI BUNTOK
}

\author{
Muhamad Hadriansyah \\ Sekolah Tinggi Ilmu Ekonomi Pancasetia Banjarmasin \\ Jl. Ahmad Yani Km. 5.5 Banjarmasin \\ ical.hadrian@gmail.com
}

\begin{abstract}
This study aims to determine the effect of workload and emotional intelligence on work fatigue (burnout) and the performance of the South Barito Police personnel. The number of research respondents was 115 personnel in the South Barito Police with data collection techniques using questionnaires and data analysis techniques used were multiple linear regression and path analysis.

The results of this study support the hypothesis that workload affects work fatigue but does not affect performance, while emotional intelligence does not affect work fatigue but has a significant effect on performance. Work fatigue has a significant effect on performance with a negative effect. The results of this study indicate that the performance of the South Barito Police has good emotional intelligence and performance as well as low levels of fatigue. The research suggestion is that the South Barito Police continue to strive to maintain personnel performance by maintaining a low level of work fatigue and workload and continue to maintain the condition of emotional intelligence by providing training to improve personnel competence, placing personnel according to their competencies so that workloads.
\end{abstract}

Keyword : workload, burnout, performance, emotional intelligence.

Abstrak : Penelitian ini bertujuan mengetahui pengaruh beban kerja dan kecerdasan emosional terhadap kelelahan kerja (burnout) dan kinerja personel Polres Barito Selatan. Jumlah responden penelitian sebanyak 115 personel di lingkungan Polres Barito Selatan dengan teknik pengumpulan data menggunakan kuisoner dan teknik analisis data yang digunakan adalah regresi linear berganda dan analisa jalur

Hasil penelitian ini mendukung hipotesis yang menyatakan beban kerja berpengaruh terhadap kelelahan kerja tetapi tidak berpengaruh terhadap kinerja, sedangkan kecerdasan emosional tidak berpengaruh terhadap kelelahan kerja tetapi berpengaruh signifikan terhadap kinerja. Kelelahan kerja berpengaruh signifikan terhadap kinerja dengan bentuk pengaruh negatif.hasil penelitian ini menunjukan bahwa kinerja Polres Barito Selatan memiliki kecerdasan emosional dan kinerja yang baik serta tingkat kelelahan yang rendah. Saran penelitian yaitu agar Polres Barito Selatan terus berusaha menjaga kinerja personel dengan cara mempertahankan tingkat rendahnya kelelahan kerja dan beban kerja serta terus menjaga kondisi kecerdasan emosional dengan cara memberikan pelatihan untuk meningkatkan kompetensi personel, menempatkan personel sesuai dengan kompetensi yang dimiliki agar beban kerja.

Kata kunci: beban kerja, burnout, kinerja, kecerdasan emosional 


\section{PENDAHULUAN}

\section{Latar Belakang}

Sumber daya manusia merupakan salah satu unsur yang penting dalam suatu organisasi. Apapun fungsi serta tujuannya, setiap organisasi tersebut dibuat atas dasar berbagai visi dalam memenuhi kepentingan manusia dan untuk pelaksanaan misi-misi organiasainya pun selalu melibatkan manusia, maka manusia merupakan faktor yang sangat strategis dalam rangkaian kegiatan suatu organisasi. Dengan adanya bidang Human Resource and Development diharapkan pengelolaan sumber daya manusia dalam sebuah organisasi lebif efektif.

Manajemen sumber daya manusia (MSDM) pada umumnya memiliki tujuan untuk memperoleh tingkat pengembangan pekerja optimal, hubungan yang baik dalam lingkungan kerja serta mengatur keserasian antar sumber daya manusia secara efektif dan efisiensi dalam kerja sama, sehingga diharapkan mampu meningkatkan produktifitas kerja. Dengan adanya sumber daya manusia yang baik maka akan muncul kompetensi yang baik sehingga kinerja yang tinggi akan muncul pula pada organisasi tersebut.

Kesuksesan dan kinerja organisasi bisa dilihat dari kinerja yang telah dicapai oleh para pegawainya, oleh sebab itu organisasi menuntut agar para karyawannya mampu menampilkan kinerja yang optimal karena baik buruknya kinerja yang dicapai oleh seorang pegawai akan berpengaruh pada kinerja dan keberhasilan organisasi secara keseluruhan. Dengan kata lain keberhasilan atau kemunduran suatu organisasi tergantung pada keahlian dan keterampilan pegawai yang bekerja di dalamnya.

Kepolisian Resor Barito Selatan adalah lembaga dalam hal pelaksana keamanan Negara di wilayah hukum Barito Selatan. Menurut Peraturan Kapolri Nomor 23 Tahun 2010 bahwa Kepolisian Resor adalah pelaksana tugas dan wewenang Polri di wilayah kabupaten/kota yang berada di bawah Kapolda.
Polres Barito Selatan memiliki peran untuk mewujudkan keamanan di Barito Selatan yang meliputi terpeliharanya keamanan dan ketertiban masyarakat, tertib dan tegaknya hukum, terselenggaranya perlindungan, pengayoman dan pelayanan masyarakat, serta terbinanya ketentraman masyarakat dengan menjunjung tinggi hak asasi manusia. Demikian pada prinsipnya pengaturan ketentuan Pasal 2, Pasal 4, danPasal 13 Undang-Undang Nomor 2 Tahun 2002 tentang Kepolisian Negara Republik Indonesia, Lembaran Negara Republik Indonesia Tahun 2002 Nomor 2 (UU Kepolisian). Dalam pengertian di atas,dapat dilihat secara organisasional maupun personal. Aspek organisasional melihat pada kelembagaan itu sendiri, sedangkan aspek personal melihat pada personel Polri yang menjalankan peran, fungsi, tugas, dan tanggung jawab dari organisasi.

Personel Polres Barito Selatan merupakan sumber daya manusia di Polres Barito Selatan yang bertugas melaksanakan tugas dan fungsi Polres Barito Selatan sesuai yang diamanatkan dalam undangundang. Kedudukan personel yang sangat sentral dalam pelaksanan tugas dan tanggung jawab Polres Barito Selatan menempatkan personel sebagai sumber daya manusia utama pemegang kunci operasional tugas dan tanggung jawab Polres Barito Selatan. Kinerja Personel sangat menentukan perkembangan organisasi Polres Barito Selatan. Oleh sebab itu, segala upaya yang dilakukan dengan tujuan untuk meningkatkan kinerja personel perlu dilakukan agar fungsi dan peran personel dapat terlaksana secara maksimal guna tercapainya tujuan organisasi.

Sebagai tenaga utama dalam pelaksanaan peran dan fungsi Polres Barito Selatan hanya memiliki jumlah personel sebanyak 280 Personel. Jumlah tersebut masih sangat minim dibandingkan jumlah Daftar Susunan Personel (DSP) yang ditetapkan pada Peraturan Kapolri Nomor 23 tahun 2010 berjumlah minimal sebanyak 800 personel, masih kekurangan sebanyak 520 orang atau kekurangan sebanyak $65 \%$. 
Dengan ketersediaan personel yang hanya sebanyak $35 \%$ dari ideal dapat kita bayangkan beban kerja yang tinggi bahwa pekerjaan yang seyogyanya dikerjakan oleh 800 orang tetapi hanya dikerjakan oleh 280 personel.

Ditinjau dari luas wilayah Kabupaten Barito Selatan seluas 8.830 kilometer persegi, apabila dibandingkan dengan jumlah personel yang ada yaitu sebanyak 280 personel, maka setiap Personel Polres Barito Selatan harus mampu menjaga 31,5 kilometer persegi luas wilayah Barito Selatan. Sedangkan dilihat dari sisi jumlah penduduk yang dirilis oleh Badan Pusat Statistik dalam buku Barito Selatan Dalam Angka tahun 2020 menyatakan jumlah penduduk Barito Selatan pada tahun 2019 adalah sebanyak 136.267 jiwa, maka dapat kita lihat perbandingan antara jumlah anggota Polri dan jumlah penduduk dengan rasio 1:486. Dikutip dari web beritasatu.com yang terbit pada 10 Maret 2014, Kapolri Saat itu Jenderal Polisi Sutarman menyatakan bahwa rasio ideal polisi dan warga adalah 1:300. Situasi ini tentu berbeda apabila terjadi demonstrasi yang mana 10 demonstran harus di diamankan oleh minimal 5 personel Polri.

Dengan berkembangnya teknologi informasi tentu tugas Anggota Polri semakin hari semakin kompleks, saat ini anggota Polri tidak hanya menangani masalah penegakan hukum dan pemeliharaan kamtibmas saja namun Polri harus mampu menjadi pelopor dalam menjaga kestabilan negeri, harus hadir ditengah-tengah masyarakat sebagai pelindung dan pelayan masyarakat, terlebih saat ini banyak bencana yang mengancam mulai dari bencana kabut asap, banjir, tanah longsor hingga yang baru-baru ini bencana mewabahnya covid-19 yang sangat mengancam kelangsungan bangsa Indonesia.

Beban tugas yang tinggi ditambah luasnya wilayah serta minimnya jumlah anggota Polri di Polres Barito Selatan, seringkali menyebabkan tumpang tindihnya pekerjaan, belum selesai pekerjaan yang diperintahkan sudah datang lagi pekerjaan baru yang harus dilaksanakan dan dengan waktu yang cepat untuk diselesaikan. Sebagai contoh personel pada Bagsumda sesuai tugas pokok dan fungsinya hanya melaksanakan tugas-tugas adminstrasi personel namun karena keterbatasan jumlah personel maka juga dilibatkan dalam kegiatan kepolisian lain. Bisa saja seorang personel yang bertugas pada Bagian perencanaan namun dalam situasi tertentu juga terlibat dalam kegiatan patroli, pengamanan dan kegiatan-kegiatan operasional lainnya. Terlebih dalam suatu operasi kepolisian dalam kondisi ini setiap anggota Polri harus siap dan tanggap atas perintah atasan tentang pelaksanaan operasi, tidak ada kata tidak bersedia walaupun sebenarnya tugas pokok personel tersebut belum selesai namun hukumnya wajib mengikuti kegiatan operasi kepolisian tersebut.

Disisi lain Polri sangat dikenal dengan tingkat kedisiplinan dan hirarki yang tinggi. Senior junior, atasan dan bawahan sangat kental di tubuh Polri sehingga kadangkadang terjadi tekanan dari atasan atau senior menyebabkan munculnya masalahmasalah dilingkungan mereka bekerja seperti stress kerja dialami para bawahan saat memiliki hubungan yang kurang baik antara atasan-atasan mereka, para bawahan juga menganggap pengaruh atasan terhadap pekerjaan mereka dapat mengganggu kinerja saat bertugas.

Dalam pelaksanaan tugas kadang muncul permasalahan-permasalahan lain. Hal ini karena Polri merupakan salah satu pelayan publik yang bersinggungan langsung dengan masyarakat sehingga pasti akan memunculkan pro kontra di tengahtengah masyarakat. Fenomena ini merupakan suatu yang wajar mengingat salah satu tugas Polri adalah penegakan hukum yang tentunya akan menimbulkan rasa tidak senang bagi beberapa pihak yang dilakukan upaya paksa oleh Polri. Dalam kondisi ini anggota polri dituntut tetap harus professional dan tidak mudah terprovokasi pada situasi yang diciptakan oleh pihak yang tidak senang dengan Polri, padahal pada setiap diri manusia pasti akan muncul 
ego saat terjadi perlawanan dan tentu hal ini akan menimbulkan tekanan atau stress pada anggota Polri tersebut.

dampak yang terlihat hingga saat ini adalah masih banyaknya personel Polres Barito Selatan yang melakukan pelanggaran disiplin dengan kasus beragam dari penyalahgunaan Narkoba, Disersi hingga permasalahan rumah tangga yang masih mendominasi pelanggaran displin di Polres Barito Selatan. dari segi kesehatan terlihat bahwa setiap hari masih ada personel Polres Barito Selatan yang tidak masuk kantor dengan keterangan Sakit, namun hingga saat ini personel Polres Barito Selatan yang mederita sakit menahun masih terdapat 1 orang.

\section{Rumusan Masalah}

1. Apakah Beban Kerja berpengaruh Signifikan terhadap Kelelahan Kerja (Bunrout) personel Polres Barito Selatan di Buntok

2. Apakah Kecerdasan Emosional berpengaruh Signifikan terhadap Kelelahan Kerja (Bunrout) personel Polres Barito Selatan di Buntok

3. Apakah beban kerja berpengaruh signifikan terhadap kinerja personel Polres Barito Selatan di Buntok.

4. Apakah kecerdasan emosional berpengaruh signifikan terhadap kinerja personel Polres Barito Selatan di Buntok

5. apakah Kelelahan Kerja (Burnout) berpengaruh signifikan terhadap kinerja personel Polres Barito Selatan di Buntok

\section{TINJAUAN PUSTAKA}

\section{Beban kerja}

Beban kerja dapat didefinisikan sebagai frekuensi rata-rata kegiatan dari pekerja dalam Menurut Peraturan Kapolri Nomor 15 tahun 2014, beban kerja adalah sejumlah target pekerjaan atau target hasil pekerjaan yang harus dicapai dalam satu satuan waktu tertentu yang diukur menggunakan analisa beban kerja yaitu teknik teknik manajemen yang dilakukan secara sistematis untuk menetapkan waktu bagi seorang pegawai negeri pada Polri dalam menyelesaikan suatu pekerjaan/tugas, program dan kegiatan yang dilaksanakan baik dalam jabatan maupun oleh unit kerjanya masing masing, guna memperoleh informasi mengenai tingkat efektivitas dan efisiensi kerja jabatan dan unit kerja yang ada berdasarkan objek dari pada Analisis Beban Kerja.

Pujiraharjo melihat beban kerja dalam dua sudut pandang yang berbeda, yaitu secara subjektif dan objektif. Yaitu beban kerja subjektif yang meliputi beban kerja fisik, beban kerja mental dan beban kerja sosial. Sedangkan selanjutnya adalah beban kerja objektif yang meliputi keadaan nyata di lapangan yang secara objektif dilihat dari jumlah total waktu yang digunakan atau jumlah total aktifitas yang dilakukan. Dalam penelitian ini, pendekatan pengukuran beban kerja yang digunakan adalah beban kerja yang dipandang dari sudut subjektif dengan menggunakan indikator pengukuran beban kerja berdasarkan 3 dimensi SWAT (Reid, 1989 dalam Purwaningsih dan Sugiyono, 2007) yaitu:

1. Time Load (beban waktu) yang menunjukan jumlah waktu yang tersedia dalam perencanaan, pelaksanaan dan monitoring tugas;

2. Mental Effort (beban usaha mental) yang berarti banyaknya usaha mental dalam melaksanakan suatu pekerjaan.

3. Psylogical Stress (beban tekanan psikologis) yang menunjukan tingkat resiko pekerjaan, kebingungan dan frustasi.

\section{Kecerdasan Emosional}

Kecerdasan emosional mencakup pengendalian diri, semangat dan ketekunan serta kemampuan untuk memotivasi diri sendiri dan bertahan menghadapi frustasi, kesanggupan untuk mengendalikan dorongan hati dan emosi, tidak melebihlebihkan kesenangan, mengatur suasan hati 
dan menjaga agar beban stres tidak melumpuhkan kemampuan berpikir, untuk membaca perasaan terdalam orang lain (empati) dan berdoa, untuk memelihara hubungan dengan sebaik-baiknya, kemampuan untuk menyelesaikan konflik serta memimpin.

Goleman mengemukakan bahwa kecerdasan emosi adalah kemampuan memotivasi diri sendiri dan bertahan menghadapi frustasi, mengandalkan dorongan hati dan tidak berlebih-lebihan dalam kesenangan, mengatur suasana hati dan menjaga agar bebas dari stres, tidak melumpuhkan kemampuan berfikir, berempati, dan berdoa. Lima Dasar Kemampuan dalam Teori Kecerdasan Emosi Menurut Daniel Goleman.

\section{Kelelahan kerja (burnout)}

Burnout merupakan sebuah sindrom yang terjadi pada individu yang ditandai dengan keadaan kelelahan, baik fisik maupun mental termasuk perkembangan konsep diri yang negatif, kurangnya konsentrasi dan perilaku-perilaku kerja yang negatif (Pines, A dan maslach, C, 1993). Keadaan tersebut membuat suasana kerja menjadi dingin, kurang menyenangkan, komitmen dan dedikasi berkurang, serta prestasi dan performa kerja kurang maksimal. Hal tersebut menjadikan adanya jarak antar pekerja dan rasa enggan untuk berbaur di lingkungan kerja. Selain itu, burnout juga dapat dipengaruhi oleh ketidaksesuaian usaha dengan apa yang telah di peroleh dari apa yang telah dikerjakan.

Dalam penelitian ini penulis mengambil indikator untuk burnout yang dideskripsikan oleh Maslach dan Jackson dengan menggunakan 3 faktor yakni: 1) depersonalisasi; 2) kelelahan emosional, dan; 3) prestasi kerja

\section{Kinerja}

Kinerja dalam Peraturan Kepolisian Negara Republik Indonesia Nomor 2 Tahun 2018 adalah hasil kerja yang dicapai oleh setiap anggota Polri pada satuan kerja/satuan fungsi/satuan wilayah sesuai dengan faktor generik dan faktor spesifik. Penilaian tersebut menggunakan Sistem Manajemen Kinerja (SMK) yaitu sistem yang digunakan untuk mengidentifikasi dan mengukur kinerja anggota Polri agar selaras dengan visi dan misi organisasi.

Kinerja sebagai hasil kerja secara kualitas dan kuantitas yang dapat dicapai oleh seseorang pegawai dalam melaksanakan tugas sesuai dengan tanggung jawab yang diberikan kepadanya (Mangkunegara, 2007). Dalam penelitian ini, pengukuran kinerja menggunakan indikator kinerja yang dikemukakan Perpol No. 2 Tahun 2018 tentang Penilaian Kinerja anggota Polri dengan Sistem Manajemen Kinerja.

\section{METODE PENELITIAN}

Penelitian ini termasuk dalam jenis penelitian kuantitatif yang bertujuan untuk menguji hipotesis penelitian dan menyandarkan kesimpulan hasilnya pada kemungkinan kesalahan penolakan hipotesis nihil. Penelitian ini juga akan dilakukan dengan menggunakan desain survei. Dalam penelitian ini, skala pengkuran dari variabel beban kerja, kelelahan kerja (burnout) dan kinerja dikukur menggunakan kuesioner yang disebar kepada sampel dari populasi anggota Polres Barito Selatan sebagai alat pengumpul data. Adapun Populasi adalah seluruh personel di lingkungan Polres Barito Selatan berjumlah 280 personel sedangkan sampel diambil menggunakan rumus 5 kali jumlah indikator, karena kuisioner berjumlah 23 indikator dikalikan 5 maka sampel ditetapkan sebanyak 115 sampel.

Teknik pengambilan sampel menggunakan probability sampling yaitu Teknik pengambilan sampel dimana seluruh elemen populasi mempunyai kesempatan yang sama untuk dijadikan sampel (Cooper dan Emory 1995). Probability sampling yang dipakai adalah dengan simple random sampling, yaitu merupakan suatu pengambilan sampel secara acak tanpa memperhatikan strata 
yang ada dalam populasi (Sugiono, 1999, p.74).

Teknik pengumpulan data dengan cara mengajukan pernyataan terstruktur dan telah tertulis pada responden terkait dengan tanggapan terhadap variabel yang sedang diteliti dengan menyebarkan kuisioner dengan piliihan yang telah tersedia, serta memanfaatkan teknologi google form. Untuk mengukur pendapat, persepsi responden digunakan skala likert 1 samapi dengan 5.

Berdasarkan permasalahan dan tujuan penelitian yang diajukan, maka data yang dikumpulkan tentang beban kerja, kecerdasan emosional, kelelahan kerja dan kinerja personel Polres Barito Selatan di Buntok diolah dan dianalisis dengan teknik analisis deskriptif dan analisis regresi linear berganda. Analisis dekriptif untuk menentukan tabel distribusi frekuensi dan persentase, sedangkan nalisis statistik dengan menggunakan menggunakan regresi linear berganda dengan dibantu aplikasi statistik PSPP.

\section{HASIL PENELITIAN DAN PEMBAHASAN}

Kepolisian Resor Barito Selatan adalah salah satu instansi dari aparat penegak hukum yang bekerja di bawah naungan Kepolisian Republik Indonesia (POLRI) dan lebih khususnya lagi berada di bawah Kepolisian Daearah Kalimantan Tengah. Karena kedudukannya sebagai alat penegak hukum maka Polres Barito Selatan Kalimantan Tengah tentunya memiliki tugas sebagaimana juga dimiliki oleh alat penegak hukum lainnya, yakni antara lain adalah untuk memelihara keamanan dan ketentraman masyarakat yang berada di wilayah kerjanya dengan visi Visi Polres Barito Selatan adalah Terwujudnya wilayah Barito Selatan yang aman dan tertib, serta misi Terwujudnya wilayah Barito Selatan yang melindungi, melayani dan mengayomi masyarakat.

\section{Gambaran Umum dan Pernyataan Responden}

Dilihat dari strata kepangkatan responden yang dominan dalam penelititan ini berpangkat Bripka yakni berjumlah 34 orang atau $29,57 \%$, menurut masa kerja diperoleh data bahwa responden didominasi oleh masa kerja 16-25 tahun yaitu sebanyak 68 personel. Ditinjau dari jenis kelamin, laki-laki merupakan responden terbanyak yaitu $91,30 \%$.

Untuk menerangkan tanggapan responden terhadap variabel penelitian maka dilakukan analisis terhadap tanggapan yang diberikan oleh responden. Kriteria hasil Penentuan kelas dari pernyataan responden terhadap variabel adalah nilai 1,00 - 1,80 disebut Sangat tidak setuju, sangat tidak baik atau sangat rendah, nilai 1,81 - 2,60 disebut tidak setuju, tidak baik atau rendah, nilai 2,61 - 3,40 disebut cukup setuju, cukup baik atau cukup tinggi, nilai $3,41-4.20$ disebut setuju, baik atau tinggi, dan yang terakhir nilai 4,21 - 5,00 nilai sangat setuju, sangat baik atau sangat tinggi.

\section{Pernyataan Responden Tehadap Beban Kerja (X1)}

Variabel beban kerja pada panelitian ini diukur melalui 3 indikator. Hasil tanggapan responden terhadap variabel beban kerja dapat dijelaskan bahwa rata-rata tanggapan responden terhadap variabel beban kerja pada nilai 2,53 yang berarti tingkat beban kerja masih berada pada tingkatan yang rendah. Dimensi indikator yang mendapat nilai tertinggi yakni beban waktu dengan rata-rata 2,99 berada pada rentang cukup tinggi sedangkan yang terendah adalah beban tekanan psikologi dengan nilai 2,28. Ini berarti tingkatan beban waktu yang dialami personel Polres Barito Selatan masih berada pada rentang cukup tinggi.

\section{Pernyataan Responden Terhadap Kecerdasan emosional (X2)}

Variabel kecerdasan emosional pada penelitian ini di ukur melalui 5 indikator, dapat diketahui bahwa ratarata skor tanggapan responden terhadap variabel kecerdasan emosional berada pada 4,28 yang berarti sangat baik. Hal 
ini menunjukan bahwa secara keseluruhan kecerdasan emosional yang dimiliki personel Polres Barito Selatan telah berada pada kategori sangat baik.

\section{Pernyataan Responden Terhadap Kelelahan Kerja (Burnout) (Z)}

Variabel kelelahan kerja (burnout) diukur melalui 3 indikator yaitu indikator kelelahan emosional, depersonalisasi dan penurunan prestasi kerja. Tanggapan responden terhadap variabel kelelahan kerja (burnout) dapat dijelaskan bahwa rata-rata skor tanggapan responden terhadap variabel kelelahan kerja (burnout) berada pada 1,9 yang berarti rendah. Hal ini menunjukan bahwa secara umum personel Polres Barito Selatan tidak merasa terjadi kelelahan saat melaksanakan tugas sebagai anggota Polri di Polres Barito Selatan.Indikator kelelahan kerja (burnout) yang mendapatkan nilai rata-rata tertinggi adalah indikator depersonalisasi dengan nilai rata-rata 2,01.

\section{Pernyataan Responden Terhadap Kinerja (Y)}

Variabel kinerja pada penelitian ini di ukur dengan 2 indikator dan 12 pernyataan, yang mana indikator Faktor Spesifik dengan 2 pernyataan dan indikator faktor generik dengan 10 pernyataan. Hasil tanggapan terhadap variabel kinerja dapat dijelaskan bahwa rata-rata skor tanggapan responden terhadap variabel kinerja berada pada rentang 4,12 yang berarti baik. Hal ini menunjukan bahwa secara keseluruhan personel Polres Barito Selatan telah memiliki kinerja yang baik.Indikator kinerja pegawai yang memiliki ratarata tanggapan tertinggi responden sebesar 4,44, nilai ini berada pada rentang nilai sangat baik untuk pernyataan "Saya tidak pernah menyalahgunakan wewenang sebagai anggota Polri" artinya tanggapan responden itu sangat baik. Hal ini menunjukan bahwa personel Polres
Barito Selatan dalam melaksanakan tugas bertanggung jawab penuh sesuai dengan tupoksi masing-masing. Selain itu indikator kinerja personel Polres Barito Selatan yang memiliki rata-rata tanggapan terendah sebesar 3,10 berada pada rentang cukup baik adalah pada faktor generik dengan bentuk pernyataan "Saya bertindak melebihi tuntutan jabatan tanpa menunggu perintah" artinya ini menunjukan bahwa masih ada personel Polres Barito Selatan dalam melaksanakan tugas masih belum memiliki inisiatif, adakalanya dapat bertindak lebih dari tuntutan jabatan tanpa menunggu perintah dengan tujuan memperbaiki/ meningkatkan hasil kerja yang tidak bertentangan dengan prosedur kerja.

\section{Uji Instrumen}

1. Uji Validitas

Keabsahan atau kesahihan hasil penelitian sangat ditentukan oleh data yang dihasilkan alat ukur yang digunakan. Untuk menguji apakah instrumen yang digunakan memenuhi syarat-syarat alat ukur yang baik atau tidak, kuisioner dinyatakan valid apabila nilai taraf signifikansi yang dihasilkan kurang dari 5\% (sig<0,05) dan korelasinya dengan variabel memadai lebih dari $0,3 \quad(\mathrm{R}>0,3)$. Dalam penelitian ini seluruh kuisioner yang disebarkan dinyatakan valid.

2. Uji Realibilitas

Uji instrumen yang kedua adalah uji realibilitas yang dimaksudkan untuk mengatahui apakah secara keseluruhan instrumen pada kuisioner yang disebar tersebut realibel atau tidak. Dalam penelitian ini uji realibilitas dilakukan menggunakan PSPP dengan teknik Reliability Analysis Statistic, jika nilai Cronbach Alpha $(\alpha)>0,60$, maka dapat dikatakan variabel tersebut reliabel. Hasil uji reliabilitas penelitian ini adalah sebagai berikut:

Tabel. Uji Realibilitas 


\begin{tabular}{|c|c|c|}
\hline Variabel & $\begin{array}{r}\text { Cronbach's } \\
\text { Alpha }\end{array}$ & $\begin{array}{r}\text { Nof } \\
\text { Items }\end{array}$ \\
\hline Beban Kerja (X1) & ,79 & 3 \\
\hline $\begin{array}{r}\text { Kecerdasan Emosional } \\
\text { (X2) }\end{array}$ & ,72 & 5 \\
\hline Kelelahan Kerja (X3) & ,62 & 3 \\
\hline Kinerja (Y) & ,85 & 12 \\
\hline
\end{tabular}
penulis)

(Sumber: Data primer diolah oleh

Dari tabel diatas bahwa nilai dapat dinyatakan bahwa nilai Cronbach Alpha $(\alpha)$ seluruh variabel lebih besar dari 0,60. Maka dapat dinyatakan bahwa seluruh variabel dinyatakan realibel.

\section{Uji Asumsi Klasik}

\section{a. Uji Normalitas}

Uji normalitas digunakan untuk mengetahui apakah data berdistribusi normal atau mendekati normal. Dapat juga pengujian reliabilitas digunakan dengan mengguji sejauh mana konsistensi internal dari sebuah konstruk (Cooper dan Schindler, 2001). Data dikatakan terdistribusi normal jika memenuhi asumsi normalitas data yaitu jika nilai dari uji KolmogrovSmirnov tidak signifikan pada $(\mathrm{p}>0,05)$ dengan kata lain residual berdistribusi normal. Jika nilai dari uji KolmogrovSmirnov signifikan pada $(\mathrm{p}<0,05)$ dengan kata lain residual berdistribusi tidak normal

Tabel. One-Sample Kolmogorov-

Smirnov

Test

\begin{tabular}{clr}
\hline & & \multicolumn{1}{c}{ RES1 } \\
\hline $\boldsymbol{N}$ & & $\mathbf{1 1 5}$ \\
\hline Normal Parameters & Mean &, 00 \\
\hline & $\begin{array}{l}\text { Std. } \\
\text { Deviation }\end{array}$ & 4,77 \\
\hline $\begin{array}{c}\text { Most Extreme } \\
\text { Differences }\end{array}$ & Absolute &, 06 \\
\hline Positive &, 03 \\
\hline Asymp. Sig. (2-tailed) & Negative &,- 06 \\
\hline
\end{tabular}

(Sumber: Data primer diolah oleh penulis)

Dari tabel di atas kita ketahui nilai signifikansinya adalah 0,833 ini artinya nilai tersebut lebih besar dari 0,05 maka data dalam penelitian ini residual berdistribusi dengan normal sehingga dapat dilanjutkan ke uji selanjutnya

b. Uji Multikolinerasitas

Multikolinearitas terjadi jika terdapat korelasi yang terlalul kuat antara variabel-variabel yang tidak duji pengaruhnya. Dalam penelitian ini disebut memiliki korelasi apabila nilai korelasinya sebesar $80 \%$ keatas dan nilai signifikansinya $<0,05$, sebaliknya apabila nilai korelasinya kurang dari $80 \%$ dan harga sig $>0,05$ maka dapat dinyatakan tidak terjadi multikolinearitas.

Tabel. Uji Korelasi

\begin{tabular}{lr}
\hline & \multicolumn{1}{c}{ KECERDASAN } \\
EMOSIONAL
\end{tabular}


dinyatakan terjadi masalah heterokedastisitas. Sebaliknya, apabila nilai signifikansinya lebih dari 0,05 maka dapat dinyatakan tidak terjadi heteroskedastisitas.

Tabel. Uji Korelasi

\begin{tabular}{|c|c|c|c|c|c|}
\hline & $\begin{array}{r}\text { Uns } \\
d \\
\text { Coe }\end{array}$ & $\begin{array}{l}\text { indar } \\
\text { ed } \\
\text { icient }\end{array}$ & $\begin{array}{l}\text { Standar } \\
\text { dized } \\
\text { Coeffici } \\
\text { ents }\end{array}$ & \multirow{2}{*}{$t$} & \multirow{2}{*}{$\begin{array}{l}S i \\
g .\end{array}$} \\
\hline & $B$ & $\begin{array}{l}\text { Std. } \\
\text { Erro } \\
\quad r\end{array}$ & Beta & & \\
\hline (Constant) & $\begin{array}{r}4,3 \\
3\end{array}$ & 2,98 & ,00 & $\begin{array}{r}1, \\
45\end{array}$ & $\begin{array}{r}, 1 \\
49\end{array}$ \\
\hline $\begin{array}{l}\text { BEBAN } \\
\text { KERJA }\end{array}$ &, 14 &, 10 & ,13 & $\begin{array}{c}1, \\
38\end{array}$ & $\begin{array}{l}, 1 \\
71\end{array}$ \\
\hline $\begin{array}{c}\text { KECERD } \\
\text { ASAN } \\
\text { EMOSIO } \\
\text { NAL }\end{array}$ & ,00 & , 12 & ,00 & $\begin{array}{r}, 0 \\
2\end{array}$ & $\begin{array}{r}\text { 99 } \\
87\end{array}$ \\
\hline $\begin{array}{c}\text { KELELA } \\
\text { HAN } \\
\text { KERJA } \\
\text { (BURNOU } \\
\text { T) }\end{array}$ & ,30 &, 14 &,- 21 & $\begin{array}{c}- \\
2, \\
16\end{array}$ & $\begin{array}{r}, 0 \\
33\end{array}$ \\
\hline
\end{tabular}

(Sumber: Data primer diolah oleh penulis)

Dari tabel di atas dapat kita uraikan bahwa variabel beban kerja memiliki nilai signifikansinya 0,171 atau $>0,05$ yang artinya variabel beban kerja tidak terjadi masalah heterokedastisitas, variabel kecerdasan emosional 0,987 atau lebih besar dari 0,05 maka dapat dinyatakan juga bebas dari masalah heterokedastisitas, sedangkan variabel kelelahan kerja (burnout) memiliki nilai signifikansi 0,033 atau kurang dari 0,05 sehingga dinyatakan terjadi masalah heterokedastisitas.

\section{Analisis Regresi Linear Berganda}

Analisis regresi linear berganda pada dasarnya untuk mengetahui pengaruh dari variabel beban kerja dan kecerdasan emosional terhadap kelelahan kerja (burnout) dan kinerja. Untuk mempermudah penelitian ini menggunakan alat bantu program statistic PSPP dengan hasil sebagai berikut:
Tabel. Coefficients (KELELAHAN

KERJA

(BURNO

UT))

\begin{tabular}{|c|c|c|c|c|c|}
\hline & \multicolumn{2}{|c|}{$\begin{array}{c}\text { Unstandar } \\
\text { dized } \\
\text { Coefficient } \\
\text { s }\end{array}$} & $\begin{array}{l}\text { Standar } \\
\text { dized } \\
\text { Coeffici } \\
\text { ents }\end{array}$ & \multirow[b]{2}{*}{$t$} & \multirow{2}{*}{$\begin{array}{l}S i \\
g .\end{array}$} \\
\hline & $B$ & $\begin{array}{l}\text { Std. } \\
\text { Erro } \\
r\end{array}$ & Beta & & \\
\hline (Constant) & 7,48 & 1,90 & ,00 & $\begin{array}{r}3, \\
94\end{array}$ & $\begin{array}{l}0 \\
00\end{array}$ \\
\hline $\begin{array}{l}\text { BEBAN } \\
\text { KERJA }\end{array}$ & ,14 & ,07 & ,20 & $\begin{array}{r}2, \\
17\end{array}$ & $\begin{array}{r}, 0 \\
32\end{array}$ \\
\hline $\begin{array}{c}\text { KECERD } \\
\text { ASAN } \\
\text { EMOSIO } \\
\text { NAL }\end{array}$ &,- 13 & ,08 &,- 15 & $\begin{array}{c}- \\
1, \\
65\end{array}$ & $\begin{array}{l}, 1 \\
02\end{array}$ \\
\hline
\end{tabular}

Pengaruh beban kerja dan kecerdasan emosional terhadap kelelahan kerja dengan nilai signifikansi beban kerja terhadap kelelahan kerja (burntout) adalah 0,032 ini berarti nilai signifiansikanya < 0,05 maka dapat dinyatakan beban kerja berpengaruh terhadap kelelahan kerja (burnout). Sedangkan kecerdasan emosional mendapat nilai signifikansi sebesar 0,102 dan dinyatakan lebih besar dari 0,05 maka dapat dinyatakan bahwa kecerdasan emosional tidak berpengaruh terhadap kelelahan kerja (burnout).

Tabel. Coefficients (KINERJA)

\begin{tabular}{|c|c|c|c|c|c|}
\hline & $\begin{array}{r}\text { Unst } \\
\text { di } \\
\text { Coefj }\end{array}$ & $\begin{array}{l}\text { adar } \\
\text { d } \\
\text { cient }\end{array}$ & $\begin{array}{c}\text { Standar } \\
\text { dized } \\
\text { Coeffici } \\
\text { ents }\end{array}$ & \multirow[b]{2}{*}{$t$} & \multirow{2}{*}{$\begin{array}{l}S i \\
g .\end{array}$} \\
\hline & $B$ & $\begin{array}{c}\text { Std. } \\
\text { Err } \\
\text { or }\end{array}$ & Beta & & \\
\hline (Constant) & $\begin{array}{r}20,4 \\
4\end{array}$ & $\begin{array}{r}4,8 \\
9\end{array}$ & ,00 & $\begin{array}{r}4, \\
18\end{array}$ & $\begin{array}{l}0 \\
00\end{array}$ \\
\hline $\begin{array}{l}\text { BEBAN } \\
\text { KERJA }\end{array}$ & , 15 & ,16 & ,07 & $\begin{array}{r}9 \\
2\end{array}$ & $\begin{array}{r}3 \\
59\end{array}$ \\
\hline $\begin{array}{c}\text { KECERD } \\
\text { ASAN } \\
\text { EMOSIO } \\
\text { NAL }\end{array}$ & 1,44 & ,20 & ,56 & $\begin{array}{c}7, \\
23\end{array}$ & $\begin{array}{l}, 0 \\
00\end{array}$ \\
\hline
\end{tabular}




\begin{tabular}{cccccc}
\hline KELELA & & & & & \\
HAN & & & & - &, 0 \\
KERJA &,- 49 &, 23 &,- 17 & 2, & 33 \\
$\begin{array}{c}\text { (BURNOU } \\
\text { T) }\end{array}$ & & & & 16 & \\
\hline
\end{tabular}

Pengaruh beban kerja dan kecerdasan emosional dan kelelahan kerja (burnout) terhadap kelelahan kerja dapat kita lihat pada tabel di atas dimana nilai signifikansi beban kerja terhadap kinerja adalah 0,359 ini berarti nilai signifiansikanya $>0,05$ maka dapat dinyatakan beban kerja tidak berpengaruh terhadap kinerja, kecerdasan emosional mendapat nilai signifikansi sebesar 0,00 dan dinyatakan $<0,05$ maka dapat dinyatakan bahwa kecerdasan emosional berpengaruh terhadap kinerja, sedangkan kelelahan kerja (burnout) mendapat nilai signifikansi sebesar 0,03 dan dinyatakan $<0,05$ maka dapat dinyatakan bahwa kelelahan kerja (burnout) berpengaruh terhadap kinerja.

\section{Analisis Jalur}

Analisis jalur adalah alat analisis yang digunakan untuk mencari pengaruh langsung dan tidak langsung dari variabel bebas terhadap variabel terikat. Analisis jalur dilakukan dengan ara melakukan analisis regresi linear berganda terhadap masing-maing-masing jalur penelitian. Penggunaan analisis kali ini menggunakan alat analisis statistic PSPP dengan nilai sig kurang dari 0,05 dan besaran pengaruhnya dilihat dari nilai standardized coefficients Bet, adapun hasil sebagai berikut:

1. Pengaruh Beban Kerja (X1) dan Kecerdasan Emosional (X2) terhadap Kelelahan kerja (burnout) (Z)

a. Beban kerja (X1) berpengaruh signifikan terhadap kelelahan kerja/burnout (Z) dengan nilai signifikansi 0,32 dan nilai standardized coefficient beta adalah 0,20.

b. Kecerdasan Emosional (X2) tidak berpengaruh signifikan terhadap kelelahan kerja/burnout (Z), hal ini dilihat dari nilai sig lebih dari 0,05 yaitu 0,102 dan nilai standardized coefficient beta adalah $-0,15$

2. Pengaruh Beban Kerja (X1),

Kecerdasan Emosional (X2) dan

Kelelahan kerja (burnout) (Z) terhadap Kinerja (Y)

a. Beban kerja (X1) tidak berpengaruh signifikan terhadap Kinerja (Y) dengan nilai signifikansi 0,35 dan nilai standardized coefficient beta adalah 0,07.

b. Kecerdasan Emosional (X2) berpengaruh signifikan terhadap Kinerja (Y), hal ini dilihat dari nilai sig lebih dari 0,05 yaitu 0,000 dan nilai standardized coefficient beta adalah 0,56

c. Kelelahan Kerja (Burnout) (Z) berpengaruh signifikan terhadap Kinerja (Y), hal ini dilihat dari nilai sig lebih dari 0,05 yaitu 0,033 dan nilai standardized coefficient beta adalah $-0,17$

maka akan menghasilkan model analisis jalur penelitian sebagai berikut:

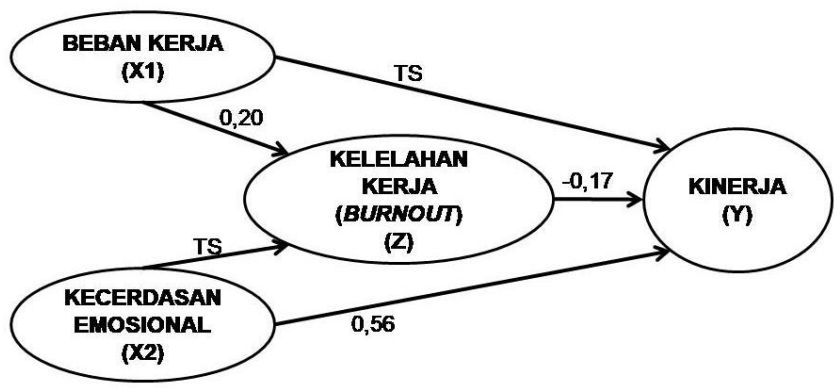

Gambar model analisa jalur penelitian

Berdasarkan pada analisa jalur diatas dapat kita buat kesimpulan sebagai berikut:

1. Beban kerja (X1) berpengaruh signifikan terhadap kelelahan kerja (burnout) (Z). Kelelahan kerja (Burnout) (Z) berpengaruh signifikan terhadap Kinerja (Y). Beban kerja (X1) tidak berpengaruh signifikan terhadap Kinerja (Y). Ini artinya Kelelahan kerja (Burnout) (Z) memberikan mediasi penuh pada pengaruh XI terhadap Y. 
maka Beban kerja (X1) berpengaruh tidak langsung terhadap kinerja.

2. Kecerdasan emosional (X2) tidak berpengaruh signifikan terhadap kelelahan kerja (burnout) (Z). Kelelahan kerja (Burnout) (Z) berpengaruh signifikan terhadap Kinerja (Y). Kecerdasan Emosional (X2) berpengaruh signifikan terhadap Kinerja (Y). Ini artinya Kelelahan kerja (Burnout) (Z) tidak memberikan mediasi pada pengaruh XI terhadap Y. maka dapat dikatakan bahwa kecerdasan emosional (X2) berpengaruh langsung terhadap kinerja (Y).

\section{Hasil Uji Hipotesis}

Sugiono (2006) menegaskan bahwa pengertian hipotesis penelitian merupakan jawaban sementara terhadap rumusan masalah penelitian. Dikatakan sementara karean jawaban yang diberikan masih memerlukan pembuktian pada faktor-faktor empiris yang diperoleh melalui pengumpulan data. Berdasarkan rumusan masalah, kerangka pemikiran dan pendapat para ahli dan teori-teori yang relevan diatas, maka pengujian terhadap hipotesis sebagai berikut:

\section{a. Hipotesis Pengaruh terhadap Kelelahan kerja (burnout)}

1. Hipotesis $1\left(\boldsymbol{H}_{\mathbf{1}}\right)$

Nilai sig beban kerja adalah senilai $0.032<0,05$ dan t-hitung $(2,17)$ lebih besar dari t-tabel (1.98137) maka dapat kita simpulkan bahwa H1: beban kerja berpengaruh terhadap kelelahan kerja (burnout) personel Polres Barito Selatan diterima dan menolak H0.

2. Hipotesis $2\left(\boldsymbol{H}_{2}\right)$

Nilai sig kecerdasan emosional terhadap kelelahan kerja (burnout) adalah senilai $0.102>0,05$ dan thitung $(-1,65)$ lebih kecil dari t-tabel (1.98137) maka dapat kita simpulkan bahwa menolak Ha2 dan menerima Ho dengan kesimpulan bahwa kecerdasan emosional tidak berpengaruh terhadap kelelahan kerja (burnout) personel Polres Barito Selatan

\section{b. Hipotesis Pengaruh terhadap kinerja}

1. Hipotesis $3\left(\boldsymbol{H}_{\mathbf{3}}\right)$

Nilai sig beban kerja terhadap kinerja adalah senilai $0,359>0,05$ dan t-hitung $(0,92)$ lebih kecil dari ttabel (1.98157) maka dapat kita simpulkan bahwa menolak Ha1 dan menerima Ho, sehingga kesimpulannya menjadi beban kerja tidak berpengaruh terhadap kinerja personel Polres Barito Selatan di Buntok.

2. Hipotesis $4\left(\boldsymbol{H}_{\mathbf{4}}\right)$

Nilai sig kecerdasan emosional terhadap kinerja adalah senilai 0,00 $<0,05$ dan t-hitung $(7,23)$ lebih besar dari t-tabel (1.98157) maka dapat kita simpulkan bahwa $\mathrm{Ha} 4$ kecerdasan emosional berpengaruh terhadap kinerja personel Polres Barito Selatan diterima dan menolak Ho.

\section{Hipotesis $5\left(\boldsymbol{H}_{5}\right)$}

Nilai sig kelelahan kerja (burnout) terhadap kinerja adalah senilai 0,033 $<0,05$ dan t-hitung $(-2,16)$ lebih kecil dari t-tabel (1.98157) maka dapat kita simpulkan bahwa Ha5 kelelahan kerja (burnout) berpengaruh terhadap kinerja personel Polres Barito Selatan diterima dan menolak Ho.

\section{Pembahasan}

Setelah seluruh data dalam penelitian ini diuraikan, maka selanjutnya akan dilakukan pembahasan dari hasil data yang telah diolah tersebut. Berdasarkan data yang diperoleh dari penyebaran kuisioner yang dilakukan oleh responden dan fakta di lapangan Maka dapat diketahui dengan pembahasan sebagai berikut:

1. Pengaruh Beban Kerja terhadap Kelelahan Kerja (Burnout) 
Dari hasil penyebaran kuisioner kepada 115 responden menyatakan bahwa kondisi beban kerja masih dalam tingkatan yang rendah hal ini di dapatkan hasil mean pada tanggapan responden senilai 2,53, ini artinya secara keseluruhan beban kerja di Polres Barito Selatan masih rendah, namun pada indicator beban waktu masih berada pada posisi rentang cukup tinggi hal ini dapat disebabkan karena masih minimnya personel Polres Barito Selatan sehingga pembagian tugas masih menumpuk pada beberapa personel.

Personel Polres Barito Selatan adalah alat Negara yang bertugas untuk menjaga ketertiban dan keamanan sesuai yang diamanatkan Undangundang, sehingga harus selalu siap siaga dalam kondisi apapun, dengan kondisi kekurangan personel yang berada pada Polres Barito Selatan tentunya akan meningkatkan beban kerja yang berujung terhadap kelelahan kerja.

Adanya pengaruh beban kerja dengan kelelahan kerja ditunjukan dengan hasil uji signifikansi senilai $0.032<0,05$ dan t-hitung $(2,17)$ lebih besar dari t-tabel (1.98137) serta nilai standardized coefficient beta adalah 0,20 (Positif). Tingkatan pengaruh yang cukup kuat antara beban kerja dengan terjadinya kondisi kelelahan kerja (burnout) Personel Polres Barito Selatan menunjukan kondisi dimana terjadinya peningkatan beban kerja akan diikuti dengan peningkatan kelelahan kerja, dengan demikian hipotesis pertama dengan hasil menolak Ho dan menerima Ha. Artinya bahwa variabel beban kerja memiliki pengaruh positif terhadap kelelahan kerja (burnout)

Pada Polres Barito Selatan, halhal yang berkaitan dengan Personel Polres Barito Selatan merupakan tugas dari Bagsumda untuk menganalisa kelelahan kerja yang dialami oleh personel dengan cara mengikutsertakan dalam pemetaan psikologi dan kesehatan jiwa serta fungsi Urusan kesehatan tentang kelelahan fisik yang dialami personel sehingga keadaan kelelahan kerja dapat diminimalisir. Namun dalam kondisi yang kelelahan kerja pasti akan menurunkan tingkat kedisiplinan personel sehingga menjadi tugas Sipropam dalam penegakkan disiplin personel Polres Barito selatan maka kendala dan dampak kelelahan kerja dapat di atasi, dimana sudah kita ketahui bahwa insitusi Polri memiliki tingkat disiplin yang tinggi.

Hal ini sesuai dengan teori yang dikemukan oleh Hasibuan (2006) bahwa kelelahan merupakan salah satu indikator dari besarnya beban kerja yang harus ditangung seorang pegawai. Banyak kasus terjadi di Indonesia bahwa pihak manajemen tidak mampu memperhitungkan kemampuan yang mampu diemban seorang pegawai untuk menyelesaikan pekerjaannya. Pimpinan tidak menyadari bahwa beban kerja yang berat berdampak negatif terhadap kinerja personel. Dampak negatif beban kerja tersebut antara lain tidak tercapainya target pekerjaan atau visi dan misi organiasai yang telah ditetapkan, rendahnya kualitas kerja personel, meningkatnya tingkat kelelahan personel yang selanjutnya akan berdampak pada tingkat absensi atau bahkan meningkatnya jumlah pelanggaran disiplin.

Menurut penelitian Arlina (2016) beban kerja yang berlebihan akan menimbulkan kelelahan baik fisik maupun mental dan reaksi emosional seperti sakit kepala, gangguan pencernaan dan mudah marah. Sedangkan pada beban kerja yang terlalu sedikit dimana pekerjaan yang terjadi karena pengurangan gerak akan menimbulkan kebosanan dan rasa monoton. Kebosanan dalam kerja rutin sehari-hari karena tugas atau pekerjaan yang terlalu sedikit mengakibatkan kurangnya perhatian pada pekerjaan 
sehingga secara potensial membahayakan pekerja.

Menurut peneliti bahwa salah satu upaya untuk mencegah, menanggulangi dan mengobati kelelahan kerja adalah melalui manajemen kelelahan kerja. Kelelahan kerja dapat diatasi melalui tindakan preventif, kuratif, dan rehabilitatif. Manajemen kelelahan kerja dapat dilakukan dalam jangka waktu pendek dan panjang. yang dapat diberikan terkait dengan manajemen kelelahan yaitu diharapkan melakukan pendidikan dan pelatihan, dimana kita ketahui bahwa tingkat pendidikan personel Polres Barito Selatan masih didominasi oleh lulusan SMA

\section{Pengaruh Kecerdasan emosional terhadap Kelelahan Kerja (Burnout)}

\begin{abstract}
Berdasarkan hasil penelitian menjelaskan bahwa pengujian hipotesis yang kedua yaitu pengaruh kecerdasan emosional terhadap kelelahan kerja (burnout) menunjukan bahwa hasil sig senilai $0.102>0,05$ dan t-hitung $(-1,65)$ lebih kecil dari t-tabel (1.98137) serta nilai standardized coefficient beta adalah $-0,15$, Sehingga hipotesis kedua dengan hasil menolak Ha dan menerima H0. Artinya bahwa variabel kecerdasan emosional tidak berpengaruh terhadap kelelahan kerja (burnout) pada personel Polres Barito Selatan.
\end{abstract}

Hal ini berbanding terbalik dengan penelitian yang dilakukan oleh Raden yang menyatakan ada pengaruh dari burnout terhadap kecerdasan emosional.

\section{a. Pengaruh beban kerja terhadap kinerja}

Berdasarkan hasil penelitian menjelaskan bahwa pengujian hipotesis ketiga yaitu pengaruh beban kerja terhadap kinerja menunjukan hasil nilai sig beban kerja terhadap kinerja adalah senilai $0,359>0,05$ dan t-hitung
$(0,92)$ lebih kecil dari t-tabel (1.98157) serta standardized coefficient beta adalah 0,07 . Hal ini menunjukan bahwa beban kerja tidak berpengaruh terhadap kinerja personel Polres Barito Selatan.

Tidak ada pengaruh antara beban kerja dan kinerja dapat diterangkan dari hasil olah data rekapitulasi responden menurut kepangkatan dengan jumlah responden terbanyak pada strata kepangkatan Bripka, hal ini dapat dinyatakan bahwa personel yang sudah menyandang pangkat Bripka tentunya sudah memiliki pengalaman yang mumpuni serta data responden menurut usia yang berada kurang dari 40 tahun yang dapat dikatakan masih energik namun juga memiliki pengalaman yang sudah matang sebagai personel Polri. Hal ini dapat diuraikan bahwa pada tingkatan strata kepangkatan Bripka dan usia masih di bawah 40 tahun tidak merasa suatu pekerjaan yang dibebankan kepadanya sebagai beban kerja yang berlebihan namun dijadikan sebagai pemicu dalam meningkatkan kinerja.

Disisi lain, Organisasi Polri dikenal memiliki Hirarki kepangkatan dan senioritas yang masih kental serta tingkat disiplin yang tinggi. Sehingga siap atau tidak siap setiap pekerjaan yang dibebankan kepada personel tersebut harus dilaksanakan apapun kondisinya, karena ada pepatah di lingungan Polri bahwa "hilang tidak dicari, gagal dicaci maki". Maka setiap pekerjaan yang tugaskan kepada insan Bhayangkara tidak dijadikan sebagai beban namun sebagi tantangan yang harus dilaksanakan Hal tersebutlah yang menjadikan beban kerja 
tidak berpengaruh terhadap kinerja pada tubuh Polri.

Temuan penelitian ini mendukung hasil penelitian sebelum yang dillakukan oleh Pulungan (2017), dimanana menyatakan bahwa beban kerja tidak berpengaruh terhadap kinerja pemeriksa BPK Perwakilan Provinsi Lampung, juga didukung oleh penelitian Hasil penelitian ini bertentangan dengan hasil penelitian dilakukan oleh Agripa Toar Sitepu pada PT. Bank Tabungan Negara Tbk Cabang Manado. Dalam penelitian tersebut menunjukan bahwa tidak ada pengaruh antara beban kerja terhadap kinerja. Dalam penelitian tersebut menunjukan

hitung $=1,497<1,685$ dan nilai signifikansi $=0,14>0,05$. Hal tersebut menjelaskan bahwa tidak ada pengaruh beban kerja terhadap kinerja. Dalam penelitian tersebut peneliti menemukan bahwa proporsi tugas dan waktu yang diberikan perusahaan pada karyawan sudah seimbang, sehingga tidak menimbulkan beban kerja yang berlebihan pada karyawan. Namun penelitian ini bertentang dengan temuan Ma'rifatu Darojati (2018), Rolos (2018) yang menyatan bahwa beban kerja berpengaruh terhadap kinerja.

\section{b. Pengaruh kecerdasan emosional terhadap kinerja}

Berdasarkan hasil penelitian menjelaskan bahwa pengujian hipotesis keempat yaitu pengaruh kecerdasan emosional terhadap kinerja menunjukan hasil nilai sig beban kerja terhadap kinerja adalah senilai $0,359>0,05$ dan $\mathrm{t}$ hitung $(0,92)$ lebih kecil dari ttabel (1.98157) serta standardized coefficient beta adalah 0,56. Hal ini menunjukan bahwa kecerdasan emosonal berpengaruh signifikan terhadap kinerja personel Polres Barito Selatan.

Berdasarkan hasil pengujian $\mathrm{t}$ yang menunjukkan bahwa "kecerdasan emosional berpengaruh positif terhadap kinerja karyawan" maka dapat disimpulkan bahwa hipotesis diterima. Hal ini disebabkan karena personel Polres Barito Selatan merasa yakin bahwa mereka memiliki kinerja yang baik.

Temuan ini selaras dengan hasil penelitian Sukmawati dan Gani Nurjaya (2014)

Hasil penelitian ini dapat menyimpulkan bahwa aspek kecerdasan emosional membantu personel Polres Barito Selatan dalam menjalankan tugas. Hal ini berarti bahwa semakin tinggi kecerdasan emosional yang dimiliki personel maka akan berdampak pada peningkatan kinerja personel Polres Barito Selatan.

Dari data responden untuk variabel kecerdasan emosional berada pada kategori sangat baik dengan nilai mean 4.28. tentu ini merupakan salah satu modal dasar bagi Polres Barito Selatan sehingga mampu menjaga tingkat kinerja yang baik sebagaimana hasil responden menyatakan bahwa tingkat kinerja Personel Polres Barito Selatan dalam tingkat baik.

Walaupun tingkat pendidikan personel Polres Barito Selatan hanya didominasi lulusan SMA namun setiap anggota Polri sebelum diangkat menjadi anggota Polri harus melalui seleksi yang ketat serta pendidikan yang salah satu 
materinya adalah Inter Personal

Skill dengan sasaran meningkatkan kecerdasan emosional setiap anggota Polri.

\section{c. Pengaruh Kelelahan Kerja (Burnout) Terhadap Kinerja}

Berdasarkan hasil penelitian ini menjelaskan hasil temuan tentang hipotesis yang kelima yaitu pengaruh kelelahan kerja (burnout) terhadap kinerja dengan hasil nilai sig kelelahan kerja (burnout) terhadap kinerja adalah senilai $0,033<0,05$ dan $\mathrm{t}-$ hitung $(-2,16)$ lebih kecil dari ttabel (1.98157) serta nilai standardized coefficient beta adalah -0,17, sehingga dapat dinyatakan bahwa kelelahan kerja (burnout) berpengaruh signifikan terhadap kinerja. Kelelahan kerja (burnout) member pengaruh negatif terhadap kinerja, artinya semakin meningkatnya kelelahan kerja (burnout) maka semakin menurun tingkat kinerja. Hal ini sejalan dengan hasil penelitian yang dillakukan oleh Ma'rifatu Darojati (2018) pada tenaga kesehatan RSUD Gambiran Kota Kediri.

Namun di lingkungan Polres Barito Selatan memiliki sistem pembinaan dan pengawasan yang dapat dikatakan sudah baik ini dibuktikan pada tahun 2018 Polres Barito Selatan mendapatkan predikat Wilayah Bebas Korupsi (WBK) dari Kementrian Pemberdayaan Aparatur Negara dan Reformasi Birokrasi yang salah satu penilaiannya adalah tingkat pembinaan dan pengawasan personel.

Di samping itu kematangan personel Polres Barito Selatan yang dapat dilihat dari strata kepangkatan yang hampir rata- rata memiliki masa dinas di atas 16 tahun, sehingga dapat mengelola kelelahan kerja dengan baik sehingga selelah apapun personel Polres Barito Selatan tetap mampu melaksanakan tugas dan kewajibannya dengan baik.

\section{KESIMPULAN}

Berdasarkan hasil penelitian dan kajian yang telah diuraikan sebelumnya, maka dapat disimpulkan menjadi beberapa hal sebagai berikut:

1. Terbukti bahwa Beban kerja mempunyai pengaruh positif yang signifikan terhadap kelelahan kerja (burnout) pada personel Polres Barito Selatan di Buntok, artinya jika beban kerja tinggi maka kelelahan kerja (burnout) juga tinggi atau sebaliknya, jika beban kerja rendah maka kelelahan kerja (burnout) juga akan turun.

2. Terbukti bahwa beban kerja tidak berpengaruh signifikan terhadap kinerja personel Polres Barito Selatan di Buntok

3. Terbukti bahwa kecerdasan emosional tidak berpengaruh signifikan terhadap kelelahan kerja (burnout) pada personel Polres Barito Selatan di Buntok

4. Terbukti bahwa kecerdasan emosional mempunyai pengaruh positif yang signifikan terhadap kinerja personel Polres Barito Selatan di Buntok, artinya jika kecerdasan emosional baik maka kinerja pun juga baik atau sebaliknya, jika kecerdasan emosional tidak baik maka kinerja pun juga tidak baik.

5. Terbukti bahwa kelelahan kerja (burnout) mempunyai pengaruh negatif yang signifikan terhadap kinerja personel Polres Barito Selatan di Buntok, dengan pengaruh negatif artinya jika kelelahan kerja (burnout) 
tinggi maka kinerja akan buruk atau sebaliknya, jika kelelahan kerja rendah maka kinerja akan baik.

\section{DAFTAR PUSTAKA}

Agripa Toar Sitepu, beban kerja dan motivasi pengaruhnya terhadap kinerja karyawan pada PT. Bank Tabungan Negara TBK Cabang Manado, jurnal EMBA Vol. 4 (Desember 2013) hal 1131

Badan Pusat Statistik. 2020. Kabupaten Barito Selatan Dalam Angka. 2020, Buntok.

Cooper, Donald R and C. William Emory. 1995. Business Research Methods, 5th Ed. Richard D. Irwin, Inc, Chicago.

Cordes, C.L., dan Dougherty, T.W. 1993. "A Review and Integration of Research on Job Burnout". Academy of Management, 18: 621-656.

Daniel goleman, kecerdasan emosional, terjemahan oleh T. Hermaya, (Jakarta:Gramedia Pustaka Utama, 2003

Darojati, Ma'rifatu. 2018. Pengaruh Beban Kerja dan Burnout Terhadap Kinerja Dengan Self-Efficacy Sebagai Variabel Intervening Pada Tenaga Kesehatan RSUD Gambiran Kota Kediri. Skripsi. Program Studi Manajemen. Universitas Islam Negeri Sunan Ampel Surabaya.

Gopher dan Doncin. 1986. Workload-an examination of the concept: chapter 41.Handbook of perception and human performance, 2. 1-49

Hasibuan, Malayu. (2009). Manajemen sumber daya manusia.Edisi revisi, PT. bumi Aksara, Jakarta.

Lijan Poltak Sinambela, Kinerja Pegawai: Teori Pengukuran dan Implikasi, (Yogyakarta: Graha Ilmu, 2012), hlm. 33

Mabes Polri, Peraturan Kapolri Nomor 15 tahun 2014 tentang Analisis Beban
Kerja di Lingkungan Kepolisian Negara Republik Indonesia. Jakarta.

Mabes Polri, Peraturan Kapolri Nomor 23 tahun 2010 tentang Susunan Organisasi dan Tata Kerja pada Tingkat Kepolisian Resort dan Kepolisian Sektor. Jakarta.

Mabes Polri, Peraturan Kepolisian Negara Republik Indonesia Nomor 2 tahun 2018 tentang Penilaian Kinerja Anggota Kepolisian Negara Republik Indonesia dengan Sistem Manajemen Kinerja. Jakarta.

Mangkunegara, Anwar Prabu. 2007. Evaluasi Kinerja SDM, Cetakan ketiga Reflika Aditama, Bandung.

Manuaba, A. 2000. Hubungan Beban Kerja Dan Kapasitas Kerja. Rinek Cipta, Jakarta.

Maslach, C dan Jackson, S. E. 1981.The Measurement of Experienced Burnout. Journal of Occupational Behavior.

Mudayana, A. A., 2013. Hubungan Beban Kerja Dengan Kinerja Karyawan Di Rumah Sakit Nur Hidayah Bantul. Jurnal Kesehatan Masyarakat. Vol. 6, No 1, PP. 1-74.ISSN : 1978-0575

Pines, A dan Aronsol, A. 1989. Career burnout: Causes and cures. The freepress, A Division of Macmillan, inc, New York.

Pines, A. \& Maslach C. 1993 Characteristics of staff burnout in mental health settings. Hospital Community Psychiatry, 29, 233237.

Purwaningsih, R., dan Sugianto, A., 2007. Analisis Beban Kerja Mental Dosen Teknik Industri Undip dengan Metode Subjective Workload Assesment Technique (SWAT), J@TI Undip, II (2), 28-39.

R. Saptoto, Jurnal Psikologi Indonesia, (Dinamika Psikologis Nrimo Dalam Bekerja: Nrimo Sebagai Motivator Atau Demotivator), 2 (6), Hlm. 131137 
Raharjo, Dwi Sihono, 2005. Kinerja Karyawan Survei di Bank Negara Indonesia dan Bank Central Asia. Jurnal Manajemen, Th IX/O1/Feb/2005, Hal 19-26.

Reid, G.B., Potter, S.S., and Bressler, J.R., 1989, Subjective Workload Assessment Technique (SWAT): A User's Guide (U), Interim Report, Harry G. Armstrong Aerospace Medical Research Laboratory, Human System Division Air Force System Command Wright-Patterson Air Force Base, Ohio.

Republik Indonesia. 2002. Undang Undang No 2 tahun 2002 tentang Kepolisian Negara Republik Indonesia. Jakarta.

Rivai, Veithzal. 2005. Manajemen Sumber Daya Manusia untuk Perusahaan, dari Teori ke Praktik. PT. Raja grafindo Persada Hlm 15 48, Jakarta.

Robbins, P. Stephen. 2003. Organizational Behaviour, Tenth Edition (perilaku
Organisasi edisi kesepuluh) alih bahasa oleh Drs. Benyamin Molan. PT. Macanan Jaya Cemerlang,

Sugiono. 1999. Metodologi Penelitian Administrasi. Edisi Kedua. CV Alfa Beta, Bandung.

Sugiyono. 2006. Metode Penelitian Kuantitatif Kualitatif dan $R \& D$. Alfabeta, Bandung.

Sukmawati dan Gani Nurjaya. 2014 Pengaruh Kecerdasan Emosional, Kepuasan Kerja dan Komitmen Organisasi Terhadap Kinerja Karyawan Pada Koperasi Karyawan PT. Telkom Siporennu Makassar. Jurnal Manajemen dan Akuntansi, Volume 3, Nomor 3, Halaman 1529.

Wikaningtyas, Theresa Sila. 2007. Hubungan antara Perilaku Tipe A dengan Stres Kerja pada Karyawan Non-Manajerial. E-journal Fakultas Psikologi Universitas Indon

esia. 